\title{
Aquinas on Physical Impairment: Human Nature and Original Sin*
}

\author{
Richard Cross \\ University of Notre Dame
}

Medieval accounts of disability by and large (though not universally) defend what is now labeled the "religio-moral" construction of disability: seeing an individual's disability as a punishment for that individual's $\sin .{ }^{1}$ Unsurprisingly, such models are not much in favor among contemporary disability theorists for a number of reasons, among which we might include the unacceptable thought that an individual with disabilities somehow deserves those disabilities. Thomas Aquinas (1225-1274) accepts some version of this theory, but one rather different from the standard one (or at least, from what is now generally understood as the religio-moral model). Aquinas sees physical impairments - things that constitute a subclass of what he labels "bodily defects"-fundamentally as punishments for original sin. He is (generally) very careful to distance his account of defects from notions of individual punishment. (When he is not, it is because of pressure from Scriptural sources - though as we shall see below he believes that by and large the Bible, too, explicitly rejects the view that disability could be a punishment for individual sin.) So whatever we think of punishment models more generally, Aquinas's certainly removes one of the least appealing aspects of such models as typically understood.

* Thanks to John O'Callaghan for careful comments on an earlier version of this paper, and to Essaka Joshua and Scott Williams for discussing some of the issues with me. A referee for this journal made some suggestions that helped me make my presentation of the case more forceful.

${ }^{1}$ For brief discussion of the religio-moral view from the perspective of contemporary disability theory, see the discussion in Dan Goodley, Disability Studies: An Interdisciplinary Introduction (Los Angeles, CA: Sage, 2011) 5-10. For some sense of the variety of views in the Middle Ages, see Irina Metzler, Disability in Medieval Europe: Thinking about Physical Impairment during the High Middle Ages, c. 1100-1400 (Routledge Studies in Medieval Religion and Culture 5; London and New York: Routledge, 2006). See also my "Duns Scotus on Disability: Teleology, Divine Willing, and Pure Nature," Theological Studies 78.1 (2017): 72-95, intended to be a companion piece to this paper, in which I explore Scotus's very different take on the issues.

HTR 110:3 (2017) 317-338 
And Aquinas is careful, too, to associate many features of the human condition - not just those identified as a certain subclass of defects - with corporate punishment for original sin. To this extent, his account of physical impairments tends to normalize such impairments, and to de-emphasize their distance from other features of postlapsarian human existence. While I doubt that what Aquinas says about bodily defects would satisfy many contemporary disability theorists, it seems to me that parts of his accout - and not least this normalization strategy - may appeal to more theologically-inflected accounts of the human condition.

My account will make clear the central importance of the notion of bodily defects in Aquinas's account of physical impairment. My choice of concept requires justification, because there is already one significant proposal on the table. In his important recent work on Aquinas on disability, Miguel J. Romero has isolated Aquinas's category of bodily infirmity (infirmitas corporis) as the relevant ancestral concept to our notion of disability. ${ }^{2}$ But while it is true that this term includes many of the bodily configurations that might be captured in (at least many) modern accounts of disability, it turns out that Aquinas has no theory of bodily infirmity. Infirmity is simply a consequence of some other state of affairs, one about which Aquinas has a fully developed theory, namely, a body's teleological failure. And it is this failure that he labels a bodily defect (defectus) - a physical impairment, as I suggest in my title above. ${ }^{3}$

\footnotetext{
${ }^{2}$ Miguel J. Romero, "Aquinas on the corporis infirmitas: Broken Flesh and the Grammar of Grace," in Disability in the Christian Tradition: A Reader (ed. Brian Brock and John Swinton; Grand Rapids, MI: Eerdmans, 2012) 101-51. Romero's account remains the best overall discussion of Aquinas. A good recent account focusing on Aquinas's teleological understanding of human nature can be found in Neil Messer, Flourishing: Health, Disease, and Bioethics in Theological Perspective (Grand Rapids, MI: Eerdmans, 2013) 141-50. See too, briefly, Terrence Ehrman, "Disability and Resurrection Identity," New Blackfriars 96 (2015) 723-38. My "Baptism and Severe Cognitive Impairment in Some Medieval Theologies," International Journal of Systematic Theology 14 (2012) 420-38, and John Berkman, "Are Persons with Profound Intellectual Disabilities Sacramental Icons of the Heavenly Life? Aquinas on Impairment," Studies in Christian Ethics 26 (2013) 81-96, focus on very specific features of Aquinas's views on cognitive impairment. Here I attempt to offer an examination of disability within the general context of Aquinas's teleology as theologically inflected by his views on original justice and the Fall-something that cannot be found other than cursorily in the extant literature (see in particular the very brief mention in Messer, Flourishing, 148, and the slightly more extensive discussion in Romero, "Aquinas on the corporis infirmitas," 112-14). So I offer this piece as something of a complement to the existing literature on the subject. For relevant earlier bibliography, see Romero, "Aquinas on the corporis infirmitas."

${ }^{3}$ I use the term "impairment" deliberately, if a little provocatively, since at least one modern theory of disability - the "social model" - uses the term to refer to the intrinsic bodily configuration of certain human bodies, as contrasted to the environmental conditions in which such bodies find themselves - the disabling environment, in the case of an environment not suitably accommodating to the impaired body: see Michael Oliver, The Politics of Disablement: A Sociological Approach (New York, NY: St. Martin's Press, 1990).
} 
What do I mean by teleological failure? In a teleological universe such as Aquinas's, there are some states, and some types of activity, which are, as he puts it, "natural, and which should be had." As Aquinas sees it, some parts of nature notably fail, either in maintaining appropriate structural integrity, or in acting in ways that are appropriate to the relevant structure, or in both:

Evil . . . is a privation of good. Good consists principally and of itself in perfection and actuality (actu). But actuality is two-fold, first [actuality] and second [actuality]. First actuality is the form and integrity of a thing. Second actuality is activity (operatio). Therefore evil can obtain in two ways: in one way, by the loss of form, or of some part which is required for the integrity of a thing - just as blindness is an evil, or the absence of a limb [is an evil]; in the other way, by the loss of due activity-either because this is entirely lacking, or because it does not have its due order. ${ }^{5}$

The idea is that a thing might be such that it lacks a power appropriate to its achieving one of its goals or that its activity fails to be appropriately goal-directed, either by being wholly lacking, or being directed in the wrong way. One representative example of the first kind of defect, as the passage just quoted makes clear, consists in various sorts of states that we might plausibly categorize under the concept of disability - blindness, or the absence of a limb, to give Aquinas's examples here.

Now, one thing I intend to do in this essay is to make a small contribution to the history of disability in the Middle Ages. But talking about the history of disability is not an unproblematic undertaking. After all, the category of disability is modern, and both contemporary theory and popular usage associate a variety of different concepts with the term "disability." And there is an array of different bodily configurations that may or may not be covered under these various concepts. (I talk about bodily configuration because both moderns and scholastics generally take cognitive impairments to have wholly bodily explanations, connected with the functioning of the brain - something I will return to briefly below.) And a significant strand of modern theorizing would hold that the concept of disability is in any case socially constructed: if the construction is not present in the Middle Ages, then (it might be thought) there is simply no history to be written. ${ }^{7}$ But whatever we might think about this, Aquinas would not have held that his notion of bodily defects

\footnotetext{
${ }^{4}$ Aquinas, Summa theologiae I, q. 48, a. 5, ad 1; for the distinction between the "integrity" of a form or state, and a "due activity," see I, q. 48, a. 5 c. I return to this passage in just a moment. Unless otherwise stated, I use the text of Aquinas's works edited by Robert Busa, at http://www. corpusthomisticum.org/iopera.html.

${ }^{5}$ Aquinas, Summa theologiae I, q. 48, a. 5 c.

${ }^{6}$ For some sense of the variety of possible theoretical approaches, see the opening chapter of Goodley, Disability Studies.

${ }^{7}$ See, for example, Shelley Tremain, "On the Government of Disability," Social Theory and Practice 27 (2001) 617-36. For what it is worth, I would resist this conclusion: that a category is conventional does not in itself say anything about whether or not the category is real: plenty of mind-dependent things are fully real-symphonies, for example, or games.
} 
was a social construction; and I take it that we should not think of the individual physical configurations of different human bodies as such constructions. Now, the various modern concepts of disability all have some kind of relationship or likeness to each other; that (presumably) is why they are associated with one and the same term. And this likeness is best seen extensionally: the various concepts generally range over the same kinds of bodily configuration-with some disagreement at the edges, but little at the core. ${ }^{8}$ (For example, deafness is considered by some to be not a disability but an identity.) ${ }^{9}$ So while it perhaps goes without saying that Aquinas does not and cannot have a concept of disability, he does have a concept under the extension of which the various bodily configurations that would roughly be captured by various contemporary concepts would fall (e.g. blindness or being a wheel-chair user). The match is not entirely neat-but neither, given the recent history and theory of the concept of disability, would we expect it to be. The best we can do is isolate some plausible ancestor to our concept or concepts, related to these contemporary concepts by some kind of approximate co-extension, and talk about that. And that is what I propose to do here.

In what follows, I first consider Aquinas's taxonomy of various relevant kinds of defects - something that, as we shall see, is constructed using fundamentally medical criteria. I then show how these relate to his notion of original sin, by showing that, according to Aquinas, they could only exist as punishments for sin: it would not have been just of God to create sinless human beings with these kinds of bodily defects. On occasion, I attempt to show how we might think about those views in light of some of the more developed theories that have emerged in the modern discipline of disability studies. In the final section of my essay, I try to show how Aquinas's account fits into his views on the problem of evil more generally.

\section{Aquinas's Taxonomy of Bodily Defects}

According to Aquinas, defects fall into two broad classes: those that do, and those that do not, impact on the teleological orientation of an organism. The second group is not relevant to our purposes, for there is nothing bad in something's lacking a perfection that is not teleologically appropriate to it: "the lack (defectum) of sight in a stone is not an evil . . . because it is against the nature of a stone to have sight." 10 But the first group is germane. Aquinas divides it in various ways. Firstly, he distinguishes universal defects from particular ones. Universal defects

\footnotetext{
${ }^{8}$ I say "kinds" of bodily configuration, fully allowing that the kinds - not the configurations themselves - could be constructed. But, irrespective of this, Aquinas would accept many of the kinds that I would accept; and there is not in fact much serious disagreement about many (not all) of these kinds even in contemporary theory, irrespective of the ontological status of these kinds. (I doubt that Aquinas would have thought of them as natural kinds.)

${ }^{9}$ For example, on the relation between deafness and disability, see National Association of the Deaf, "Position Statement on Cochlear Implants (2000)," http://nad.org/issues/technology/assistivelistening/cochlear-implants.
}

${ }^{10}$ Aquinas, Summa theologiae I, q. 48, a. 5 ad 1. 
affect everyone-e.g., negative bodily affections (e.g., pain, hunger), ${ }^{11}$ and various kinds of cognitive or behavioral dysfunction. ${ }^{12}$ Particular ones do not: for example, "leprosy, blindness, fever, and such like things: for these arise from particular corruptions in individual persons."13

Secondly, defects are classified as to the degree of teleological failure involved. Some defects disrupt an organism's existence - they destroy a "principle of life"; others do not. Aquinas distinguishes the second of these into those disorders that destroy a natural principle of activity, and those that do not. This gives us three kinds of teleological failures: (1) defects that destroy the organism; (2) defects that destroy a natural principle of activity; (3) defects that destroy neither the organism nor any of its natural principles of activity - any of its settled causal powers. Aquinas makes the distinction between the first and the third of these-between a disorder that disrupts existence and a disorder that does not destroy any natural principle of activity - in the context of his discussion of the distinction between mortal and venial sin. The distinction is presented as a medical matter between incurable and curable illness:

We should consider that sin consists in a certain disordering of the soul, just as sickness (morbus) consists in a certain disordering of the body. Thus, sin is like a certain sickness of the soul. And pardon (venia) is to sin what healing is to sickness. Therefore, just as some sicknesses are curable, and some incurable (which are called mortal), so there are some sins which are in a way curable (which are called venial), and some, even though they can be cured by God, which are of themselves incurable (which are called mortal). A sickness by which some principle of life is destroyed is said to be incurable and mortal. For if this is destroyed, nothing remains through which it can be restored; and therefore such a sickness cannot be cured, but brings about death. But there is some sickness which does not destroy any of the principles of life, but [destroys] something that follows on the principles. These can be restored through the principles of life: for example, tertian malaria, which consists in an excess of bile, which the power of nature can overcome. ${ }^{14}$

The distinction between the second and the third categories - between those defects that irrevocably destroy any principle of activity, and those that do not - is likewise drawn in a medical way, in terms of incurability and curability:

A thing can destroy an order either reparably or irreparably. A defect through which a principle is permanently taken away is irreparable; but if the prin-

${ }^{11}$ See Aquinas, Summa theologiae III, q. 14, a.1 c.

${ }^{12}$ See, for example, the set of "defects of the soul" that Aquinas considers in Summa theologiae III, q. 15. For some of the varieties of cognitive impairment, see Romero, "Aquinas on the corporis infirmitas," 111.

${ }^{13}$ Aquinas, Scriptum super sententiis III, d. 15, q. 1, a. 2 c.

${ }^{14}$ Aquinas, De malo, q. 7, a. 1 c. See too Summa theologiae I-II, q. 72, a. 5. Aquinas makes curability rather too wide in scope here: not every condition that destroys "something that follows on the principles [of life]" can be restored, as we shall see in the next quotation. 
ciple is preserved, then in virtue of that principle the defect can be repaired. For example, if the principle of sight is destroyed, sight cannot be restored other than by divine power; but if, while the principle of sight be preserved, some impediment should come to sight, it can be restored either by nature or by science. ${ }^{15}$

The category relevant to disability is the second one. For example, at one point Aquinas gives as examples of configurations "repugnant to the integrity of nature," "blindness, and weakness of the limbs." 16 Aquinas, then, has a category that roughly corresponds to what we might think of as physical impairments. (In what follows, I shall use "impairment" as a term of art to pick out Aquinas's second category of bodily defects.) His way of highlighting that category is medical. Thus, the distinction between the first and second categories - those categories of configurations that remove something teleologically required for a nature - is between those that consist in life-threatening conditions and those that are non-lifethreatening but nevertheless incurable. Just like mortal sins and life-threatening illnesses, such defects can be remedied, but only by God. ${ }^{17}$

I draw attention to the medical approach that Aquinas brings to the taxonomic task because contemporary theories of disability by and large find other criteria to do the relevant work. One reason for this is that the so-called "medical model" of disability - seeing disability fundamentally as a medical problem to be solvedis now widely discredited. ${ }^{18}$ But we should note that using a medical taxonomic principle does not amount to seeing disability as a fundamentally medical matter (as in the medical model): as I suggested above, and as I now proceed to show, Aquinas's theory of physical impairment is best seen as a kind of religio-moral theory of disability - a punishment theory.

\section{Bodily Defects and Original Sin}

Aquinas accepts a strong account of divine providence: "The intention of universal nature depends on God, who is the universal author of nature"; ${ }^{19}$ and he holds further that "there is nothing done in vain in God's works." ${ }^{20}$ This might make the presence of physical impairments rather puzzling. A robust understanding of divine providence might, after all, suggest that a nature should attain its goal — that

${ }^{15}$ Aquinas, Summa theologiae I-II, q. 87, a. 3 c.

${ }^{16}$ Aquinas, Scriptum super sententiis III, d. 15, q. 1, a. 2 sed contra; see also the very first passage quoted above. For a relatively complete list of the different kinds of bodily states identified by Aquinas that we would identify as disabilities, see Romero, "Aquinas on the corporis infirmitas," 110-11.

${ }^{17}$ For mortal sin and life-threatening illness, see, e.g., Aquinas, De malo, q. 7, a. 1 c; Summa theologiae I-II, q. 72, a. 5.

${ }^{18}$ See, e.g., Goodley, Disability Studies, 5-10.

${ }^{19}$ Aquinas, Summa theologiae I, q. 92, a. 1 ad 1.

${ }^{20}$ Ibid., q. 67, a. 4 ad 2. 
it maintain both structural integrity and due activity. Indeed, Aquinas expressly affirms that God cannot have purposes that are frustrated, whether in particular or in general:

The causality of God, who is the first agent, extends itself to all things, not only in relation to the principles of a species but also in relation to individual principles. ... Whence it is necessary that all things that have existence in any way are ordered by God to a goal. ${ }^{21}$. . Something can fall outside the order of a particular cause, but not outside the order of a universal cause. For nothing falls outside the order of a particular cause other than through some other particular impeding cause. . . . Whence, since all particular causes are held under the universal cause, it is impossible for some effect to escape the order of the universal cause. ${ }^{22}$

For example, the generation of a woman, on Aquinas's account, is the result of the failure of a particular cause, but not of the general intentions of God, who, for other teleological purposes, has planned for this failure, and needs it to achieve some ultimate goal in divine providence - in this case, the overall good of the kind, which requires male and female for reproduction. ${ }^{23}$ Physical impairments are not like this: they are the simple absence of powers necessary for the achievement of a given appropriate goal, with no necessary good for the kind. And, according to Aquinas, if they are in any way good for the individuals that possess them, that goodness is quite incidental to the presence of the impairment: ceteris paribus, the individual would have been better off without the impairment, in the sense that the individual with impairments lacks something teleologically appropriate to his or her nature, and lacks it in a way not necessary for the overall teleological structure of the whole universe.

Such teleological failure, according to Aquinas, is not a necessary feature of the actual world, although its possibility is:

The perfection of the universe requires inequality to be in things, so that all degrees of goodness are realized. But there is one degree of goodness according to which something is so good that it can never be defective. And there is another degree of goodness according to which something is good in such a way that it can fall away from the good..$^{24}$

So it is necessary that God make things that can fall away from their teleological goals. But why should God permit a universe in which this kind of defectiveness is actually realized?

\footnotetext{
${ }^{21}$ Ibid., q. 22, a. 2 c.

${ }^{22}$ Ibid., q. 22, a. 2. ad 1.

${ }^{23}$ Ibid., q. 92, a. 1 ad 1.

${ }^{24}$ Ibid., q. 48, a. 2 c.
} 
Aquinas proposes that the existence of physical impairments is the result of human sin-specifically, of the original sin of Adam, although God's providence extends as much to the post-lapsarian as to the pre-lapsarian state. Indeed, Aquinas sometimes even uses "defect" as a technical term to characterize the features specific to fallen humanity. ${ }^{25}$ To understand what is going on, it is important to keep in mind that the privations that Aquinas is talking about are losses or privations only in relation to what human nature had in ideal circumstances. These ideal circumstances were realized in human beings prior to the Fall. In short, human nature after the Fall becomes defective in this negative sense-it lacks the internal ordering imposed on it in the pre-lapsarian state.

\section{Integral Nature}

To grasp what Aquinas has to say about these kinds of defects and their place in the divine plan, we need to see what he says about the pre-lapsarian state. This turns out to be rather complex. Aquinas holds that, prior to the Fall, human beings, as a matter of fact, had both justifying or saving grace and what Aquinas calls "original justice." ${ }^{26}$ Aquinas has a technical term, "integral nature," to refer to the state of humanity prior to the Fall, but in abstraction from grace: that is to say, the term refers to the state of human nature with the virtue of original justice, and does so whether or not the state includes grace. ${ }^{27}$ Thus, Aquinas sometimes wonders about various counterfactuals concerning the pre-lapsarian state: could people in the state of integral nature but without grace "will and do the good"; ${ }^{28}$ could they "love God above all";29 could they "merit eternal life"; 30 could they "prepare themselves for grace"; 31 could they "raise themselves from sin"; 32 and could they "avoid sin altogether"? ${ }^{33}$ He claims that such people could will and do the good, love God above all, and avoid sin altogether. But they could not merit, or have any causal role in, the gift of grace. Why? Because grace is a supernatural gift, while the other acts are natural to a well-ordered human life. Thus, as Aquinas elsewhere notes, human nature has an "inclination to virtue," and original justice was a "good of nature" in the sense that it was (or would have been) "conferred on the whole of human nature." 34

${ }^{25}$ See, e.g., Aquinas, Summa theologiae III, q. 14, a. 1 obj. 3.

${ }^{26}$ Aquinas, Summa theologiae I-II, q. 113, a. 1 c. For a detailed account of original justice, and its relation to justifying grace, see William A. van Roo, Grace and Original Justice according to St. Thomas (Analecta Gregoriana 75; Rome: Gregorian University, 1955).

\footnotetext{
${ }^{27}$ See Aquinas, Summa theologiae I-II, q. 109, a. 2 c.

${ }^{28}$ Ibid., q. 109, a. 2.

${ }^{29}$ Ibid., q. 109, a. 3.

${ }^{30}$ Ibid., q. 109, a. 5.

${ }^{31}$ Ibid., q. 109, a. 6.

${ }^{32}$ Ibid., q. 109, a. 7.

${ }^{33}$ Ibid., q. 109, a. 8.

${ }^{34}$ Ibid., q. 85, a. 1 c.
} 
Original justice has certain clearly specified functions:

[Original] rectitude consisted in the fact that reason was subject to God, the lower powers to reason, and the body to the soul. The first subjection was the cause of the second and third, for as long as reason remained subject to God, the lower powers were subject to it. . . But it is clear that the subjection of the body to the soul, and of the lower powers to reason, was not natural; otherwise it would have remained after $\sin .^{35}$

Reason includes the power for rational choice; and the lower powers include bodily desires. With original justice, we are able to avoid irrational choice, and we are able to avoid simple subjection to our bodily desires. But with original justice the body is also subject to the soul: the body is such as to allow us to do what we can reasonably desire to do in accordance with human nature. There was, therefore, no place for intellectual or physical impairment. (When Aquinas states that this situation was not "natural," he means to pick out merely the minimal requirements for being human. "Natural" for Aquinas is an equivocal term, and I return in a moment to the relevant disambiguation.)

But it is important in this context to keep in mind what original justice does not achieve in the state of integral nature. It does not make human beings immortal or impassible, for example. Human beings are naturally mortal because of the physical requirements of a body suitable for being structured by a human soul. ${ }^{36}$ The fact that pre-lapsarian humans were immortal (and would have remained immortal had there been no Fall) is the result of an additional divine gift:

It was not in virtue of some vigor of immortality existing in it that [Adam's] body was indestructible. Rather, there was in his soul a certain supernatural power, divinely given, through which he could preserve his body from all corruption, for as long as he remained subject to God. ${ }^{37}$

And impassibility prior to the Fall is construed very weakly: a human being could not have been acted upon in a way which would have been inimical to "his natural disposition," 38 but this was partly the result of his own "reason, through which he could avoid what is harmful, and partly through divine providence." 39

It might be thought odd that the teleologically natural human condition - integral nature - requires more than just human bodily configuration, that it requires some kind of divinely-imposed virtue. But in Aquinas's Aristotelian world, human beings are free and have a teleological function that requires for its achievement the presence of various kinds of mental dispositions - virtuous habits of the intellect and appetite, disposing the agent to act in one way (a teleologically appropriate

${ }^{35}$ Aquinas, Summa theologiae I, q. 95, a. 1 c.

${ }^{36}$ Aquinas, De malo, q. 5, a. 5 c: "A body suitable for such a soul was a body composed of contraries. Therefore it follows, from the necessity of matter, that it is corruptible."

${ }^{37}$ Aquinas, Summa theologiae I, q. 97, a. 1 c.

${ }^{38}$ Ibid.

${ }^{39}$ Ibid., q. 97, a. 1 ad 4. 
way) rather than another. In the absence of such virtues, a free human being cannot regularly act in ways appropriate to her nature. Justice thus construed is what Aquinas, following Aristotle, elsewhere calls "justice taken metaphorically"- the kind of justice that refers to the (teleologically) "required coordination" of the powers of an individual human being. ${ }^{40}$ As it happens, original justice is a divinely given virtue (or something like a virtue). ${ }^{41}$ But Aquinas's counterfactual exploration of the possible activities of a human being in the state of integral nature without grace suggests very strongly that there is nothing necessarily supernatural about its function - it is not the kind of virtue that can lead its possessor to achieve the ultimate goal of the vision of God. After all, the counterfactual cases posit original justice without grace. But without grace there is no (supernatural) virtue of charity ${ }^{42}$ and without charity there are no "perfect" virtues at all (and, I suppose, no perfect justice in the metaphorical sense either). ${ }^{43}$ What there are (or would be) are virtues of such a degree that

they attain right reason; but they do not attain God himself, through charity. These are in some way perfect in relation to the human good, but are not, simply speaking, perfect, because they do not attain the first rule, which is the ultimate goal. ${ }^{44}$

Thus, with the kind of justice that rightly orders the internal dispositions of a human being, such a person can do good, love God above all, and avoid sin: components of a natural human good - a "human goal of some sort." ${ }^{45}$ I draw attention to this, not to naturalize Aquinas's account of original justice (after all, as far as I know, he persistently talks about it as a divine gift), but rather to show that a non-defective token of human nature requires not merely a certain bodily configuration but also certain additional virtuous dispositions necessary for achieving the goal appropriate to human teleology; and that this is as true of the kinds of subordinate goals that Aquinas ascribes to the possessor of natural, acquired, Aristotelian-style virtues, as it is of someone with justifying grace. Lacking original justice is a human defect; and, as I show in the next subsection, the bodily consequences of this lack are defects, too.

\section{Post-Lapsarian Defects and Impairment}

On the issue of original sin, the idea is that God gave the gift of original justice not to any individual but to the species as a whole:

${ }^{40}$ Aquinas, Summa theologiae II-II, q. 58, a. 2, ad 1; see Aristotle, Ethica nicomachea, V, c. 11 (1138b5-14).

${ }^{41}$ See Aquinas, Summa theologiae I-II, q. 113, a. 1 c.

${ }^{42}$ See Aquinas, Summa theologiae I-II, q. 110, a. 3 sed contra and ad 1.

${ }^{43}$ See Summa theologiae I-II, q. 65, a. 2 c.

${ }^{44}$ Aquinas, De virtutibus, q. 5, a. 2 c.

${ }^{45}$ Aquinas, Summa theologiae I-II, q. 65, a. 2 c. 
Original justice, in which the first human being was created, was an accident of the nature of the species, not, as it were, as something caused by the principles of the species, but as a certain gift, divinely given to the whole nature. ${ }^{46}$

The contrast is between two kinds of (ceteris paribus) universal but non-essential features of a kind: those that are "caused by the principles of a nature" - things that Aquinas would think of as propria, the so-called "necessary accidents" that naturally flow from an individual's kind-nature without being in any way constituent parts of this nature ${ }^{47}$-and those that are caused directly by God. Original justice is the second kind of these, and the explanation of its presence (or absence) is God. Given that the gift is universal, its loss is too. So once the gift is lost, it is lost to the whole species:

Something can pertain to a nature in itself-for example, what is caused by its principles - and something [can pertain to the nature] from the gift of grace. And in this way original justice ... was a certain gift of grace to the whole of human nature, divinely conferred on the first parent, and which this first human being lost through the first sin. Therefore, just as this original justice would have been transmitted to descendants at the same time as the nature, so too the opposed disorder [was transmitted to descendants at the same time as nature]. ${ }^{48}$

Aquinas holds that this loss of original justice has a number of further results. It diminishes a human being's natural inclination to virtue, thus diminishing the "good of the nature" in one sense. It also results in the total loss of both grace and original justice, destroying the "good of the nature" in a second sense. ${ }^{49}$ But it does not "destroy or diminish . . . the principles of the nature, by which the nature is constituted, or the properties caused by these [principles], such as the powers of the soul and other such things." ${ }^{50}$ As noted in a passage quoted earlier, the gifts of original justice are not (in this sense) "natural," and Adam's sin does not destroy the "good of [human] nature" in this sense. So (at least some of) the propria of human nature are left intact after the loss of original justice, but not all of them are. Aquinas makes a distinction (which, as far as I know, he never spells out explicitly) between two kinds of propria: those that are necessary for the existence of a substance, and those that are necessary for its integrity, but not for its existence. As we have just seen, he clearly maintains that some of the propria of a thing - some of the properties "caused by" the principles of the nature - are necessary to it. For example, original sin does not destroy or diminish "the powers of the soul," but to which powers does Aquinas refer? Aquinas distinguishes between the powers of the soul that belong to the soul, and the powers of the soul that belong to the composite of

\footnotetext{
${ }^{46}$ Aquinas, Summa theologiae I, q. 100, a. 1 c.

${ }^{47}$ See, e.g., Aristotle, Topica I, c. 5 (102a18-30).

${ }^{48}$ Aquinas, Summa theologiae I-II, q. 81, a. 2 c; see too I, q. 100, a. 1 c.

${ }^{49}$ See Aquinas, Summa theologiae I-II, q. 85, a. 1 c.

50 Ibid.
} 
body and soul, the human person. The former consist in intellect and will, the latter in bodily powers (e.g., for sensation and life). ${ }^{51}$ Both are explained by the presence of the soul-both "flow from" the essence of the soul. ${ }^{52}$ The former are those that persist through the loss of original justice. Thus, Aquinas holds that many kinds of cognitive impairment are simply the consequence of bodily defects, not of any intrinsic defect in the soul. ${ }^{53}$ It is other causal powers and dispositions - those that are required for natural integrity but not for existence-that become defective in consequence of the loss of original justice. ${ }^{54}$

Members of this latter group are, in the post-lapsarian world, caused merely "for the most part," and thus there is no logical contradiction involved in their absence in given cases. As Aquinas puts it,

The good proportioned to the common state of a nature happens for the most part (ut in pluribus), and defects from this good only in a few cases (ut in paucioribus). But the good that exceeds the common state of a nature is found only in a few cases, and defects from this good [are found] for the most part. ${ }^{55}$

The idea is that the goods proportioned to a nature are caused by it, but (in the post-lapsarian world) not invariably. And in the case of the kinds of propria that are relevant for our purposes, the causal relation is an instance of efficient causation: as Aquinas puts it, the nature is "in some way an active cause" (as well as a "final" and "material" one) ${ }^{56}$ Like many relations of efficient causation, the effect occurs sometimes, but - given the possibility of impediment - not universally.

With original justice, then, there are no defects, and thus (I take it) these kinds of causal explanations are universal (but not necessary, of course). But in the postlapsarian world, the deprivation of the gift of original justice results in the loss of the various mental and bodily configurations, the presence of which is explained by original justice, and which are among the things required for the integrity of a nature:

The sin of the first parent is the cause of death and of all of these sorts of defects [viz. death and other bodily defects] in human nature, in so far as original justice - through which not only were the lower powers of the soul held together under reason, without any disorder, but also the whole body was held together in subjection to the soul, without any defect ... - was

${ }^{51}$ Aquinas, Summa theologiae I, q. 77, a. 5 c.

${ }^{52}$ Ibid.

${ }^{53}$ See, e.g., Aquinas, Summa theologiae I, q. 87, a. 1 c; II-II, q. 15, a. 1 . As Aquinas makes clear, even those with very severe cognitive impairments have reason, but they cannot use it because of some impediment in their bodily configuration: see Aquinas, Summa theologiae III, q. 68, a. 12 ad 2. Romero and Berkman make a great deal of this fact in their discussions of Aquinas on severe cognitive impairments (see Romero, "Aquinas and the corporis infirmitas," 113-14; Berkman, "Persons with Profound Intellectual Disabilities," 93-96).

${ }^{54}$ For the status of all of those powers and properties that "flow from" the soul as propria, see Aquinas, Summa theologiae I, q. 77, a. 1 ad 5.

${ }_{55}^{5}$ Aquinas, Summa theologiae I, q. 23, a. 7 ad 3.

${ }^{56}$ Ibid., q. 77, a. 6 ad 2. 
removed through the sin of the first parent. And for this reason, once original justice was removed by the sin of the first parent, just as human nature was wounded in relation to the soul, by the disorder of its powers ... so it was made corruptible by the disorder of the body itself. ${ }^{57}$

Strictly speaking (though Aquinas does not make it explicit) these cases are rather different: bodily immortality is the result of a special divine grace over and above original justice; the lack of other bodily defects is the result simply of original justice. So the loss of original justice ipso facto results in bodily defects; death must be the result of the deprivation of an additional gift. But death is not my subject here, and I ignore this quibble in what follows. What we learn from the passage that is germane to my purposes is that impairment and illness-like all post-lapsarian defects - are the result of the loss of original justice: the loss of the organism's teleologically-appropriate self-control.

Aquinas has a very clear explanation of the link between the deprivation of original justice and the different varieties of bodily configurations that are associated with its loss:

When original justice is lost, the nature of a human body is left to itself, and in this way, even though original sin is equal, the bodies of some are subject to more defects, and of others to fewer, according to the natural diversity of their configuration (complexionis).$^{58}$

The idea is that different bodily configurations, in the absence of original justice, naturally result in different kinds of defects. We might think, then, of the variety of post-lapsarian bodily configurations as the result of the lack of original justice coupled with counterfactual bodily configuration, that is, the body as it would have been configured had it had original justice. Now, the loss of original justice is the same in all, and thus drops out as part of the explanation for the variety of postlapsarian bodily configurations. This variety, in other words, is wholly the result of counterfactual bodily configuration: different counterfactual configurations explain different factual configurations and the variety of defects that these configurations necessarily involve in the absence of original justice. Among these post-lapsarian configurations are different kinds of impairment. But impairment is not something particular, or unusual: it is just another of the set of defects that are realized disjunctively by all human beings. The crucial determinant is counterfactual bodily configuration, and how that configuration plays out in the absence of original justice.

This, it seems to me, is the most theoretically appealing aspect of what Aquinas has to say: there are no "normal" bodies - and thus no "abnormal" bodies - but just bodies as such, in all their great variety. ${ }^{59}$ This account of post-lapsarian defect

${ }^{57}$ Aquinas, Summa theologiae I-II, q. 85, a. 5 c.

${ }^{58}$ Ibid., q. 85, a. 5 ad 1.

${ }^{59}$ For the classic criticism of the notion of the normal in constructing or analyzing notions of disability, see Lennard J. Davis, Enforcing Normalcy: Disability, Deafness, and the Body (American Council of Learned Societies; London and New York, NY: Verso, 1995). For a good summary of the 
does not put impairment into some radically different category from other defects: all humans, after the Fall, are defective in various ways; disability is just one of those defects - not, admittedly, itself universal, but one of a set that is disjunctively universal.Aquinas has, in effect, normalized impairment, while remaining sensitive to the differences between the various kinds of human affliction. (What Aquinas says about counterfactual identity might, incidentally, seem rather implausible: after all, how might the various kinds of right-ordered subjection required for original justice - of reason to God, of lower powers to higher powers, and of body to soul-relate to the number of limbs a person has, for example? But I am interested here not in practical plausibility but in detecting theoretical value on other grounds. Doubtless it would be possible to identify some way of fixing the problem.)

The notion of counterfactual bodily configuration itself raises a teleological question: what would have been the purpose of the variety of human configurations had there been no Fall? In response, Aquinas simply notes that inequality without defect is the result both of particular divine planning and of the natural workings of the physical order. On the first (divine planning), he argues that inequality without defect is brought about by God "so that the beauty of order should more greatly shine out in humankind." ${ }^{60}$ And on the second (the natural workings of the physical order), he claims:

There might also have been bodily disparity [before the Fall]. For the human body was not totally exempt from the laws of nature, so as not to receive to a greater or lesser extent something useful or helpful from external agents, just as human lives were sustained by food. And in this way, nothing prevents us from saying that, according to the different dispositions of air and the different situations of the stars, some would have been generated with stronger bodies than others, and some taller, more beautiful, and better constituted, nevertheless such that, in those who are excelled, there would be no defect or sin, either in body or soul. ${ }^{61}$

The variety of pre-lapsarian human bodily configurations was intended by God to add to the beauty of the universe, and was perhaps the immediate result of the physical situation of such bodies. And note in this last passage the explicit references to bodily configuration (strength, height, beauty, general constitution).

\section{Impairment and Punishment}

Thus far I have spoken about bodily defects as among the automatic consequences of the loss of original justice: what happens to human bodies in the absence of that particular virtue. But Aquinas believes too that the loss of original justice is

literature, including copious relevant references, see Tanya Titchkosky, "Normal," in Keywords for Disability Studies (ed. Rachel Adams, Benjamin Reiss, and David Serlin; New York and London: New York University Press, 2015) 130-32.

${ }^{60}$ See Aquinas, Summa theologiae I, q. 96, a. 3 ad 3.

${ }^{61}$ Ibid., q. 96, a. 3 c. 
something culpable - not only in Adam, but also in his descendants. The case of Adam is simple enough: Adam sinned, and God withdrew original justice as a punishment. ${ }^{62}$ Aquinas appeals to a theory of corporate responsibility to secure the guilt of Adam's descendants: the human race forms a community, rather like a city does, and the parts of that community can be held responsible for the actions of the head of that community - that is to say, of Adam, the "first moving principle of human beings." ${ }^{3}$ On this view, then, all human beings descended from Adam are automatically guilty of original sin and deserving of punishment. And Aquinas claims that the defects that are the automatic consequences of the loss of original justice are included among the relevant punishments:

The removal of original justice has the character of a punishment. . . . Therefore also death and all the consequent bodily defects are certain punishments for original sin . . ordered according to the justice of the God who punishes. ${ }^{64}$

Aquinas goes into some detail on the nature and taxonomy of punishment, and the place of these kinds of losses within that taxonomy:

Whatever are contained under an order are in some way one, in an order to the principle of the order. So whatever rises up (insurgit) against some order is repressed (deprimatur) by that order, or by the principle of the order. But since $\sin$ is a disordered act, it is clear that whoever sins acts against some order. And therefore the consequence is that the sinner is repressed by that order. Therefore according to the three orders to which the human will is subject, a human being can be punished by a three-fold punishment. For human nature is firstly subject to the order proper to reason; secondly, to the order of an external person governing him, whether spiritually or temporally, politically or as belonging to a household; thirdly, it is subject to the universal order of divine rule. Each of these orders is perverted through sin: whenever someone sins, he acts against reason, against human law, and against divine law. Whence he incurs a three-fold punishment: one from himself, which is the remorse of conscience; one from man; and one from God. ${ }^{65}$

According to Aquinas, punishment is part of the natural order of things: something's acting so to repress an object that has repressed it. ${ }^{66}$ In what does "repressing" the subject of punishment consist? What is it, in short, for a person to be punished? It is for that person to be subject to the evil that consists in "the loss of form, or of the integrity of the thing." 67 That is to say, it is for the subject of punishment to be rendered in one way or another teleologically defective. This is presented by

${ }^{62}$ See Aquinas, Summa theologiae I-II, q. 81, a. 1 c, and I-II, q. 85, a. 5 c.

${ }^{63}$ Ibid., q. 81, a. 1 c.

${ }^{64}$ Ibid., q. 85 , a. 5 c.

${ }^{65}$ Ibid., q. 87, a. 1 c.

${ }^{66}$ For a thorough treatment of this issue, see Peter Karl Koritansky, Thomas Aquinas and the Philosophy of Punishment (Washington, DC: Catholic University of America Press, 2011).

${ }^{67}$ Aquinas, Summa theologiae I, q. 58, a. 5 c. 
Aquinas as a definition of punishment: any case in which a "voluntary agent" (i.e., what we would call a person) is deprived of the integrity of a nature counts as a punishment. For the purposes of our discussion here, the relevant case is the third: bodily defects are among the punishments inflicted by God for the disorder of sin, committed against the universal order of divine government.

Aquinas, then, at heart holds some kind of punishment model of disability. It is very important to avoid thinking that Aquinas holds that an impairment might be a punishment for an individual's sin, that is, for the sin of the person with the impairment. Aquinas's insight that physical impairment is a punishment allows him expressly to reject this view. He makes the point most clearly, about defects in general, in the commentary on Job:

If it were true, as Eliphaz was trying to claim, that the proper punishments of sins were the adversities of the present life, it would follow that men would suffer grave adversities because of grave sins and light adversities because of light sins, and so just men would never be subjected to grave adversities, which is patently false. ${ }^{6}$

Impairment cannot, on pain of injustice, count in general as a punishment for an individual's sin — and God's action cannot be unjust. Indeed, Aquinas comments about the book of Job that "temporal adversity is not the proper punishment for sins, and the discussion in the whole book will generally concern this point." 69 Whatever else impairment is, it is not generally a punishment for the sins of the subject of the impairment. ${ }^{70}$ And, as we have seen, it is part of the punishment for

${ }^{68}$ Aquinas, Super Job, c. 6, 11. 18-24 (Aquinas, Opera omnia 26; Rome: Santa Sabina, 1965) 41a; English translation, The Literal Exposition on Job: A Scriptural Commentary Concerning Providence (trans. Anthony Damico; AAR Classics in Religious Studies Series; Atlanta, GA: Scholars Press, 1989) 137.

${ }^{69}$ Aquinas, Super Job, c. 1, 11. 522-4 (11a; Damico 82).

${ }^{70}$ Recent writing on disability has sometimes tended to view the punishment model of disability construed as a theory which explains disability as a punishment for an individual's actual sins - as the model propounded in the Bible. Aquinas usually argues - very plausibly in my view - that it is a view that at least some of the Biblical writers were anxious to correct. He finds the view in Job's comforters (see Super Job, c. 2, 11. 208-11 [18b; Damico 95]), Jesus's disciples (see Super Ioannem, c. 9, lect. 1, n. 1296 [ed. R. Cai; Turin and Rome: Marietti, 1952] 241b; English translation, Commentary on St. John. Volume 2: Chapters 6-12 [trans. James A. Weisheipl and Fabian Larcher; Washington, DC: Catholic University of America Press, 2010] 157), and Jesus's opponents (see Super Ioannem, c. 9, lect. 3, n. 1353 [252a; Weisheipl and Larcher 177]). But he generally sees the view as decisively rejected in both Job and John's gospel (I have just given the relevant quotation for the former; for the latter, see Super Ioannem, c. 9, lect. 1, n. 1299 [242b; Weisheipl and Larcher 158]). Sadly, there is at least one exception to this. When discussing the cure of the mobility-impaired man at the pool of Bethesda, Aquinas wonders why Jesus admonishes only some of those whom he has cured to "sin no more," and offers three possible solutions, the first of which seems in tension with his thoughts elsewhere: "Why did our Lord mention sin to this paralytic and to certain others that he cured, and not to the rest? He did this to show that illness comes to certain people as a result of their previous sins, according to: 'For this reason many of you are weak and sick, and many have died' [1 Cor 11:30]. In this way he even showed himself to be God, pointing out sins and the hidden secrets of the heart: 'Hell and destruction are open to the Lord; how much more the hearts of the 
original sin, something communal for which all human beings are punished, in their different ways. ${ }^{71}$

This insight, indeed, is apparently what motivates Aquinas's views about the significance of counterfactual bodily configuration. The loss of original justice is equal in all; so, Aquinas wonders, how is it that the array of post-lapsarian bodily configurations seems so unevenly distributed?

If the cause is equal, the effect is equal. But these kinds of defects [viz. death and other bodily defects] are not equal in all, but in some people these kinds of defects are more profuse, whereas original sin, of which these defects seem most greatly to be the effect, is equal in all. . . Therefore death and suchlike defects are not the effect of $\sin ^{72}$

children of men' [Prov 15:11]. And so Christ mentioned sin only to some he cured and not to all, for not all infirmities are due to previous sins: some come from one's natural disposition, and some are permitted as a trial, as with Job. Or, Christ might have brought up sin to some because they were better prepared for his correction: 'Do not rebuke one who mocks, lest he hate you; rebuke a wise man, and he will love you' [Prov 9:8]. Or, we could say, in telling some not to sin, he intended his words for all the others": Super Ioannem, c. 5, lect. 2, n. 733 (137b; English translation, Commentary on St. John. Volume 1: Chapters 1-5 [trans. James A. Weisheipl and Fabian Larcher; Washington, DC: Catholic University of America Press, 2010] 266), commenting on John 5:14. Presumably Aquinas makes the concession under exegetical pressure.

${ }^{71}$ Note that this normalization strategy does not prevent Aquinas from using physical impairment, and its divine cure, as metaphors for sin and justification. Again, when discussing the story of the cure at Bethesda, Aquinas comments at some length on the identities of those lying by the pool-a group of the weak (languentium), the blind, the lame (claudorum), and the paralyzed (aridorum) (John 5:3). He first notes the literal sense of the text: "since all the afflicted persons gathered because of the curative power of the water, which did not always cure nor cure many at the same time, it was inevitable that there be many hanging around waiting to be cured": Super Ioannem, c. 5, lect. 1, n. 705 (132a-b; Weisheipl and Larcher 256). Aquinas then goes on to explain at great length the mystical sense. The posture of the people-lying down - is a trope for human sinfulness, facing down towards earthly things (Aquinas, Super Ioannem, c. 5, lect. 1, n. 706 [132b; Weisheipl and Larcher p. 256]). The large number of the group represents the large number of sinners (Aquinas, Super Ioannem, c. 5, lect. 1, n. 706 [132b; Weisheipl and Larcher 256-57]). Each of the different conditions correlates to a feature of sinful humanity - weak subjection to passion (Aquinas, Super Ioannem, c. 5, lect. 1, n. 706 [132b; Weisheipl and Larcher 257]); blind consent to passion (Aquinas, Super Ioannem, c. 5, lect. 1, n. 706 [132b; Weisheipl and Larche, 257]); unsteadiness in moral action (Aquinas, Super Ioannem, c. 5, lect. 1, n. 706 [132b; Weisheipl and Larcher 257]); inability to turn to God (Aquinas, Super Ioannem, c. 5, lect. 1, n. 706 [132b; Weisheipl and Larcher 257]). The healing and subsequent actions of the man represent justification: "These are the three things which the Lord commands in the justification of a sinner. First, he should stand up, by leaving his sinful ways: 'Rise up, you who sleep, and arise from the dead' [Eph 5:14]. Secondly, he is commanded to pick up your mat, by making satisfaction for the sins he has committed. For the mat on which a man rests signifies his sins. And so a man takes up his mat when he begins to do the penance given to him for his sins. 'I will bear the anger of God, because I have sinned against him [Mic 7:9]. Thirdly, he is commanded to walk, by advancing in what is good, according to: 'They will go from strength to strength' [Ps 83:8]": Aquinas, Super Ioannem, c. 5, lect. 1, n. 717 [134b; Weisheipl and Larcher 261]). Still, the normalization of impairment takes away some of the negative implications of such analogies.

${ }^{72}$ Aquinas, Summa theologiae I-II, q. 85, a. 5 obj. 1. 
The answer is spelled out in the response to this objection, the penultimate text quoted in the previous subsection: counterfactual bodily configuration.

\section{Punishment, Teleology, and the Problem of Evil}

This might all sound rather unpalatable, but we can make some sense of it if we recall that, for Aquinas, this kind of punishment, far from being simply an evil, is itself in some way a good. As we saw above, Aquinas holds that, to the extent that a punishment necessarily deprives a person of some actuality necessary for a certain kind of teleological goal, the punishment is an evil. But inasmuch as it achieves other purposes, it is to that extent a good. (Recall that there is nothing, for Aquinas, that is wholly evil, wholly devoid of good. $)^{73}$ There is, according to Aquinas, one type of punishment that wholly deprives human beings of their ultimate teleological functioning: eternal damnation. This kind of punishment is not at all a good for its subject. ${ }^{74}$ But even so, such a punishment is a good in the sense that it "preserves divine justice" 75 — something that all punishment is supposed to do, according to Aquinas. ${ }^{76}$ (Again, recall that punishment is the repression of injustice, as outlined above.) Clearly, physical impairment does not fall into this category, and (so Aquinas maintains) it does some good to its subject, like all other non-eternal punishments.

Aquinas devotes considerable space to the precise sense in which those bodily defects that serve some derivative teleological purpose for their possessor count as goods. Basically, he makes it clear that they count as such goods, provided that they contribute to a person's spiritual health:

We should keep in mind that sometimes something appears to be punitive, but does not simply speaking have the nature of a punishment. For punishment is a species of evil. . . And evil is the privation of good. But there are many goods for a human being: namely, of the soul, of the body, and of external circumstances. But it happens sometimes that a human being can suffer loss in some lesser good, so that he may increase in a greater-just as someone might suffer pecuniary loss for the sake of the health of the body, or loss of both of these for the sake of the salvation of his soul and the glory of God. And this loss is not simply speaking evil for a human being, but only qualifiedly so. Therefore it does not simply speaking have the nature of a punishment, but of medicine: for in this way a doctor prescribes bitter medicines to his patients, so that they might confer health. But because these

${ }^{73}$ See, e.g., Aquinas, Summa theologiae I, q. 48, a. 4.

${ }^{74}$ See, e.g., Aquinas, Summa theologiae I-II, q. 87, a. 5 c.

${ }^{75}$ Aquinas, Scriptum in sententiis IV, d. 46, q. 1, a. 3 ad 4. It serves some other good purpose too: while punishments that deprive a person of life or salvation - capital punishment and damnation - are solely punitive for the subject of the punishment, they are salutary for others: see Aquinas, Scriptum in sententiis IV, d. 46, q. 1, a. 3 ad 3; they act as some kind of "medicine" for others, helping them to "abstain from sin": Aquinas, Summa theologiae I-II, q. 87, a. 3 ad 2; for punishment that is merely salutary, without the punitive component, see n. 80 below.

${ }^{76}$ See, e.g., Aquinas, Summa theologiae I-II, q. 87, a. 6 c. 
kinds of thing do not properly have the nature of a punishment, they are not properly speaking reduced to guilt as to their cause, other than to an extent (pro tanto), because the fact that it is necessary for human nature to sustain punitive medicines results from the corruption of nature, which is the result of original $\sin .^{77}$

There is a sequence here. The corruption of nature - a punishment for sin - results in various bodily configurations. Some of these serve a purpose for the overall spiritual well-being of the organism. But these configurations are only "to an extent" punishments for original sin, presumably because they are such only as a result of their being the automatic consequences of something that is the direct punishment for original $\sin$. Aquinas is not claiming that the medicinal purpose of certain types of suffering prevents them from counting as punishments. As we have just seen, he explicitly states that all post-lapsarian bodily defects are punishments for original sin. But he is saying that punishment can include non-retributive functions - in particular, those punishments that he classes as "punitive medicine."

The most exhaustive discussion of such non-retributive punitive functions occurs in the commentary on John's gospel, where Aquinas (borrowing from Gregory the Great) discerns four possible non-retributive purposes for the punishment that consists in physical defects: the correction of past faults (i.e., such that the person learns not to behave in that way again); the preservation from future faults (i.e., by being a disincentive against such faults); the encouragement of virtue; or the manifestation of divine glory (i.e., by being an occasion for God to make himself known). ${ }^{78}$ In the Summa theologiae, Aquinas makes the point specifically about "fevers and demonic possessions":

These kinds of defects, in those who have just been born, or in children, are the effects and punishments of original sin. ... But these defects are ordered, according to divine providence, to human salvation, either of those who suffer them, or of others, who are admonished by the punishments; and also [they are ordered] to the glory of God. ${ }^{79}$

Basically, then, Aquinas holds that punishment can consist of both retributive and non-retributive purposes. Both involve the deprivation of some teleologicallyorientated function. But acknowledging the non-retributive component does not

${ }^{77}$ Ibid., q. 87, a. 7 c.

${ }^{78}$ Aquinas, Super Ioannem, c. 9, lect. 1, n. 1302 (p. 243a; Weisheipl, 159-60), referring to Gregory the Great, Moralia in Job, praef. 5, n. 12 (PL, 75, col. 523A-B); for the material in the last parenthesis, see Aquinas, Super Ioannem, c. 9, lect. 1, n. 1300 (242b; Weisheipl and Larcher 159). Aquinas adds a fifth purpose too, a punitive one, again borrowing from Gregory: these kinds of "afflictions" are "sometimes . . the beginning of damnation": Aquinas, Super Ioannem, c. 9, lect. 1, n. 1302 (243a; Weisheipl and Larcher 159). This view sits rather uneasily with Aquinas's usual claim that disability cannot be the punishment for an individual's sin. Perhaps Aquinas was simply reporting Gregory's view without endorsing it: though see my comments at the end of n. 70 above.

${ }^{79}$ Aquinas, Summa theologiae I-II, q. 87, a. 7 ad 1. See too Aquinas, Summa theologiae I, q. 21 , a. 4 ad 3. 
require denying the retributive one. So none of Aquinas's discussion involves denying that the defects (including but not restricted to what we would call disability) in fact count as punishments for original sin. Aquinas's point is simply that they are not wholly bad, and even that the good for a person might outweigh the bad (though not, of course, such that the person would not be overall better without original $\sin$ at all) - though in such a case they would still count as retributive punishments. ${ }^{80}$ But note, again, Aquinas's normalizing of disability: it is true enough, for him, that physical impairment can increase a person's spiritual health. But the same is true of all of the universal disorder involved in post-lapsarian bodily existence.

Now, the view that bodily defects in general count as punishments raises two important questions. First, could these defects exist without their counting as a punishment for sin? Could they have counted as part of some (counterfactual) divine plan independent of original sin? We might put the question even more precisely: would the emergence of the bodily configurations that automatically result from the loss of original justice have been a just state of affairs if it were not also the case that these configurations count as a punishment for that loss? (The relevant contrasting case is that of being female: a non-optimal configuration [according to Aquinas] that exists without counting as a punishment for sin, and that he would certainly count as part of at least some counterfactual divine plans independent of original $\sin$.) If the answer to this question is affirmative, then disability could have been, or could be, a part of the divine plan independent of original sin: it could be part of what God antecedently wants for the universe. And in this case, what Aquinas says about disability could, even by his lights, have some kind of application quite independent of its penal component. Secondly, however, if the answer to the first question is negative, we might wonder further how these relevant defects fit into

${ }^{80}$ It is in the light of this distinction that we can understand Aquinas's view that children can be punished for the sins of their parents. In the deprivation of teleological function in such cases, the medicinal purpose is divorced from the punitive: "To understand why one person is punished on account of the sins of another, we must realize that a punishment has two aspects: it is an injury and a remedy. Sometimes a part of the body is cut off to save the entire body. And a punishment of this kind causes an injury insofar as a part is cut off, but it is a remedy insofar as it saves the body itself. Still, a doctor never cuts off a superior member to save one which is inferior, but the other way around. Now in human matters, the soul is superior to the body, and the body is superior to external possessions. And so it never happens that someone is punished in his soul for the sake of his body, but rather he is punished in his body as a curing remedy for his soul. Therefore, God sometimes imposes physical punishments, or difficulties in external concerns, as a beneficial remedy of the soul. And then punishments of this kind are not given just as injuries, but as healing remedies. Thus, the killing of the children of Sodom was for the good of their souls: not because they deserved it, but so they would not be punished more severely for increasing their sins in a life spent in imitating their parents. And in this way some are often punished for the sins of their parents": Aquinas, Super Ioannem, c. 9, lect. 1, n. 1297 (242a; Weisheipl and Larcher, 158); see too Summa theologiae I-II, q. 87. a, 8; De malo, q. 5, a. 4 c. As the quoted passage suggests, Aquinas's motivation for the view that children can be punished for the sins of their parents is biblical-namely, the story of Sodom and Gomorrah (Genesis 19:23-24): see Super Ioannem, c. 9, lect. 1, n. 1296 (242a; Weisheipl and Larcher 157-58). 
the divine plan, given the reality of the Fall. Are they merely punishments, or do they serve some further non-punitive function?

As far as I can tell, Aquinas's answer to the first question is indeed negative: the deprivation of original justice can be part of a divine plan only if it counts as a punishment for sin; and hence those defects, the only explanation of which is that they are consequences of the deprivation of original justice, can likewise be part of a divine plan only if they count as (or as the consequences of) a punishment for $\sin$. As we have seen, the kinds of disorder that Aquinas has in mind are those that consist in the lack of something "required for the integrity of a thing." And, as we have also seen, any such lack in a person - in a voluntary agent - is counted by Aquinas as a punishment. Indeed, Aquinas holds that it is a matter of justice that, other things being equal, human beings have the structure that is teleologically appropriate to their nature: it is, for example, "due to . . . a human being that he have hands." ${ }^{81}$ Any lack of something that is otherwise justly given to someone is a punishment for sin.

But this takes me on to my second question: given that these defects are primarily punishments for sin, do they serve any further purpose too? As we have seen, Aquinas thinks that punishment itself can serve non-retributive purposes. But could the relevant defects serve purposes other than those associated specifically with punishment? Aquinas does not say much on this. But he believes that there is at least one non-punitive function of disability: to provide opportunities for care:

All other [bodily] necessities are reduced to these [viz. feeding the hungry, giving drink to the thirsty, clothing the naked, giving shelter to guests, visiting the sick, releasing the prisoner, and burying the dead]. For both blindness and lameness (claudicatio) are kinds of infirmity: therefore, leading the blind and supporting the lame are classified as visiting the sick. ${ }^{82}$

And this gives us Aquinas's take on one worry that might arise on the view that disability is nothing other than punishment: namely, that the punishment view would make it wrong to attempt to mitigate these "defects" at all, since they are punishments for sin, and since it is good for sins to be punished (for some or all of the reasons outlined above). But the good of care shows that this is wrong (even in the context of Aquinas's theory): there are many ways of restoring an order, and punishment is only one of them. Recall that, in general, Aquinas holds that "there are many goods for a human being: namely, of soul, of body, of external circumstances." Consider too the case of a medicalized defect-illness. Aquinas is quite clear that it is a good thing to mitigate this particular defect-in this case

${ }^{81}$ Aquinas, Summa theologiae I-II, q. 21, a. 1 ad 3.

${ }^{82}$ See Aquinas, Summa theologiae, II-II, q. 32, a. 2 ad 2. For more extensive discussion of this, see Romero, "Aquinas on the corporis infirmitas," 119-20. 
by medical practice and cure. ${ }^{83}$ So - thinking in non-medicalized terms - Aquinas would clearly be very sympathetic to attempts to remove disabling environments in order to allow those with impairments to flourish. ${ }^{84}$

But does not the good of care constitute an objection to Aquinas's view that the deprivation of original justice cannot be a good other than in the context of its function as punishment? I do not think so. On the one hand, it is true that Aquinas holds there are many objectively bad things, permitted by God in a fallen universe, that serve some good purpose as a result of which their presence makes the universe that they are part of objectively better than it would have been in their absence. For example, he thinks it a bad thing that there are tyrannical persecutors of Christians, but that in their absence there would nevertheless be some goods lacking from the universe: in this case, "the patience of martyrs." ${ }^{85}$ And he holds in general a teleology according to which the goodness of many such situations outweighs the harm of their absence, at least in a post-lapsarian context. Thus, he holds that the presence of things that can be defective means that there will be cases of things that are defective (the one fact "follows from" the other, as Aquinas puts it). ${ }^{86}$ And if this were not the case, "many kinds of goodness would be lacking from the universe." ${ }^{87}$ But still, on the other hand, the mere fact that the universe is made better by such-and-such a defect is not a sufficient justification for the presence of the defect in the case of every kind of defect. And physical impairment without its punitive justification would indeed be a defect that would not make its universe better. Defects that prima facie involve injustice, with no teleological gain other than the added variety of the universe, are not such that the universe is better with them than it would be without them. The requirements of justice trump those of variety.

${ }^{83}$ On curing blindness, see, e.g., Aquinas, Summa theologiae I-II, q. 87, a. 3 c. In general, medicine imitates the workings of nature to produce the same result of health: see Aquinas, In libros Physicorum II, lect. 13, n. 501; Summa contra gentiles II, c. 75, n. 15.

${ }^{84} \mathrm{Such}$ is the case with the social model of disability, mentioned at n. 3 above.

${ }^{85}$ Aquinas, Summa theologiae I, q. 22, a. 2 ad 2.

${ }^{86}$ Ibid., q. 48, a. 2 c.

${ }^{87}$ Ibid., q. 22, a. 2 c. On all of this, and Aquinas's views on the problem of evil more generally, see John F. X. Knasas, Aquinas and the Cry of Rachel: Thomistic Reflections on the Problem of Evil (Washington, DC: Catholic University of America Press, 2013) 145-46. 